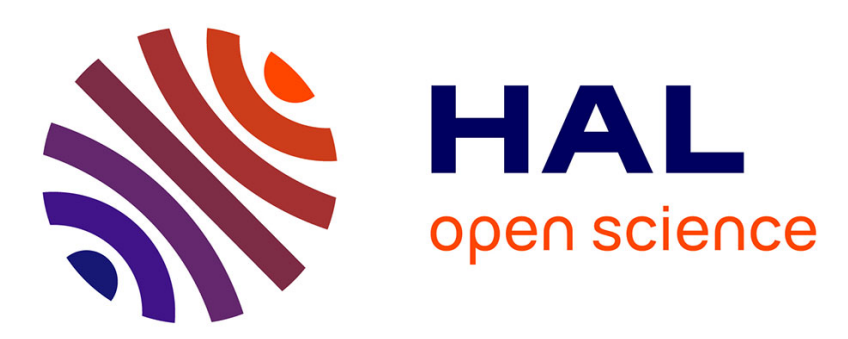

\title{
Invertebrate communities in gravel-bed, braided rivers are highly resilient to flow intermittence
}

\author{
R. Vander Vorste, R. Corti, A. Sagouis, T. Datry
}

\section{To cite this version:}

R. Vander Vorste, R. Corti, A. Sagouis, T. Datry. Invertebrate communities in gravel-bed, braided rivers are highly resilient to flow intermittence. Freshwater Science, 2016, 35 (1), pp.164-177. 10.1086/683274 . hal-01691540

\author{
HAL Id: hal-01691540 \\ https://hal.science/hal-01691540
}

Submitted on 24 Jan 2018

HAL is a multi-disciplinary open access archive for the deposit and dissemination of scientific research documents, whether they are published or not. The documents may come from teaching and research institutions in France or abroad, or from public or private research centers.
L'archive ouverte pluridisciplinaire HAL, est destinée au dépôt et à la diffusion de documents scientifiques de niveau recherche, publiés ou non, émanant des établissements d'enseignement et de recherche français ou étrangers, des laboratoires publics ou privés. 


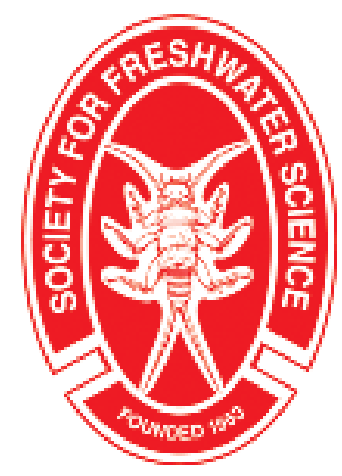

Invertebrate communities in gravel-bed, braided rivers are highly resilient to flow intermittence

Author(s): R. Vander Vorste, R. Corti, A. Sagouis and T. Datry

Source: Freshwater Science, (-Not available-), p. 000

Published by: The University of Chicago Press on behalf of Society for Freshwater Science

Stable URL: http://www.jstor.org/stable/10.1086/683274

Accessed: $11 / 08 / 2015$ 02:23

Your use of the JSTOR archive indicates your acceptance of the Terms \& Conditions of Use, available at

http://www.jstor.org/page/info/about/policies/terms.jsp

JSTOR is a not-for-profit service that helps scholars, researchers, and students discover, use, and build upon a wide range of content in a trusted digital archive. We use information technology and tools to increase productivity and facilitate new forms of scholarship. For more information about JSTOR, please contact support@jstor.org. 


\title{
Invertebrate communities in gravel-bed, braided rivers are highly resilient to flow intermittence
}

\author{
R. Vander Vorste ${ }^{1,5}$, R. Corti ${ }^{2,6}$, A. Sagouis ${ }^{3,4,7}$, and T. Datry ${ }^{1,8}$ \\ ${ }^{1}$ IRSTEA, UR MALY, 5 Rue de la Doua, CS70077, F-69626 Villeurbanne, France \\ ${ }^{2}$ Leibniz-Institute of Freshwater Ecology and Inland Fisheries (IGB), Müggelseedamm 310, 12587 Berlin, Germany \\ ${ }^{3}$ IRSTEA, UR HYAX, 3275 Route Cézanne, F-13100 Aix-en-Provence, France \\ ${ }^{4}$ IRSTEA, UR LISC, 9 Avenue Blaise Pascal, F-63172 Aubière, France
}

\begin{abstract}
In naturally disturbed systems, harsh environmental conditions act as filters on the regional species pool, restricting the number of taxa able to form a local community to those with traits promoting resistance or resilience. Thus, communities in highly disturbed ecosystems may be less sensitive to a given disturbance than those in less disturbed ecosystems. We explored this idea by examining the response of aquatic invertebrate communities to flow intermittence in gravel-bed, braided rivers (BRs). Flow intermittence is considered a major driver of communities in rivers, but its influence on communities in BRs, which are recognized as naturally highly disturbed environments, is relatively unexplored. We used a multisite Before-After-ControlImpact (BACI) design to quantify the effects of drying events of different durations (moderate: 2-3 wk, severe: 1-3 mo) on invertebrate communities in 8 BRs in southeastern France. As predicted, no effects of flow intermittence were detected 1 to 4 mo after flow resumption on taxonomic richness, composition, or functional diversity of communities facing moderate drying events. Communities subjected to severe drying events were similar to those in perennial reaches as few as $19 \mathrm{~d}$ after flow resumption. Moreover, communities showed functional redundancy and no loss of functional diversity after drying events. These results differ from those of studies in other river systems, where persistent effects of flow intermittence on communities generally have been found, and highlight the need for cross-system comparisons that explore the effects of drying on communities. Identifying the processes (e.g., niche selection, cotolerance) and habitat features (e.g., hyporheic zone refugia) that promote community resilience in BRs will advance our understanding of how anthropogenic stressors and climate change may affect communities in freshwater ecosystems.
\end{abstract}

Key words: resistance, resilience, recovery, co-tolerance, hyporheic zone, alluvial rivers, BACI design

One pervasive goal of community ecology is to identify processes that determine variation in taxonomic richness, composition, and abundance of communities (Leibold et al. 2004, Vellend 2010). Disentangling the different processes involved in community assembly and the spatiotemporal scales at which they operate and interact is essential to predict the responses of communities to future environmental changes (Götzenberger et al. 2012). At broad scales, evolutionary processes, climate (e.g., precipitation and temperature regime), and historical events act together to determine a regional species pool (Poff et al. 1997). Furthermore, the potential for taxa in the regional species pool to form a local community is a function of a series of selective filters, including the abiotic environment and biotic interactions, which operate over multiple nested habitat levels (Leibold et al. 2004). Thus, the persistence of a taxon in a local community depends on whether it possesses a combination of traits (life history, morphological, mobility, and ecological) to pass through multiple habitat filters (niche theory; Whittaker et al. 1973).

In naturally disturbed ecosystems, abiotic environmental conditions border on extreme values and are often unstable or stochastic, so fewer taxa from the regional species pool are available to form a local community (Chase 2007, Lepori and Malmqvist 2009). Therefore, taxa rely on combinations of traits (i.e., strategies sensu Southwood 1988) that promote resistance, resilience, or both to disturbances (Stanley et al. 1994, Fritz and Dodds 2004). Resistance is the capacity of a taxon, community, or ecosystem to persist unchanged through a disturbance, whereas resilience is its capacity to recover (return to predisturbance levels or similarity with undisturbed sites) after the disturbance

E-mail addresses: ${ }^{5}$ vandervorste.ross@gmail.com; ${ }^{6}$ corti@igb-berlin.de; ${ }^{7}$ alban.sagouis@irstea.fr; ${ }^{8}$ thibault.datry@irstea.fr

DOI: 10.1086/683274. Received 25 August 2014; Accepted 16 February 2015; Published online 10 August 2015.

Freshwater Science. 2015. 35(1):000-000. ๑ 2015 by The Society for Freshwater Science. 
(Stanley et al. 1994, Datry et al. 2014a). Resistance strategies generally include physiological and morphological traits (e.g., resistance to heat or to shear stress), whereas resilience strategies are related to movement/dispersal from sources of colonization (Williams 2006). Furthermore, traits that enhance resistance and resilience to one type of disturbance also can increase tolerance to other disturbances, a concept termed positive cotolerance (Vinebrooke et al. 2004). Consequently, communities in very disturbed ecosystems, where multiple and disparate disturbances occur with relatively high frequency, may show a limited response to a discrete disturbance (Vinebrooke et al. 2004, Côté and Darling 2010).

Gravel-bed, braided rivers (BRs) provide an archetype of naturally highly disturbed ecosystems, making them good systems in which to explore the response of communities to disturbances (Tockner et al. 2010). In BRs, multiple disturbances occur frequently in the form of predictable and stochastic floods and drying events (Arscott et al. 2002, Tockner et al. 2010). Habitat turnover rates are extremely high in BRs. For instance, $60 \%$ of the aquatic habitat can change to terrestrial habitat in $<2.5 \mathrm{y}$ because of bed scouring and channel movements (van der Nat et al. 2003). During periods of low flow, most, if not all, of the braided channel network becomes dry in areas of largescale downwelling, where surface water infiltrates into the groundwater. In contrast, areas of large-scale upwelling generally have perennial surface flow (Malard et al. 2003, Doering et al. 2007). Despite the physically harsh environmental conditions, BRs harbor, at the catchment scale, rich invertebrate communities composed of taxa with resistance and resilience strategies (e.g., Arscott et al. 2002, Gray and Harding 2007).

BRs experience multiple natural disturbances, but most research has focused on the effects of floods (e.g., Scrimgeour et al. 1988, Olsen and Townsend 2005), leaving the response of communities to channel drying relatively unexplored (but see Sagar 1983, Fowler 2004). Flow intermittence (i.e., the periodic loss of surface water in river channels) is considered a major driver of river communities and can induce declines in taxonomic richness and shifts in community composition and functional diversity that may persist for several months to years after flow resumption (e.g., Arscott et al. 2010, Bogan et al. 2013, Datry et al. 2014a). However, communities in BRs may be less affected by drying than those from other intermittent rivers because their constituent taxa possess traits that promote resistance and resilience. For example, invertebrate taxa in habitats subject to frequent floods and bed scouring possess traits, such as small body size and high mobility, that allow them to navigate interstitial spaces in river beds to escape harsh surface flows (Townsend and Hildrew 1994, Statzner and Bêche 2010). These same traits allow taxa in intermittent reaches to recover quickly after drying by migrating from nearby drying refuges (Bonada et al. 2006, Robson et al. 2011), including the underlying hyporheic zone (i.e., saturated interstitial areas beneath the river bed; White 1993), which is expansive in BRs (Capderrey et al. 2013). However, the factors that promote the resistance and resilience of communities may be curtailed by the duration or severity of drying events, which is considered one of the main flow-regime components driving the response of communities (e.g., Poff et al. 1997, Lytle and Poff 2004). Severe drying events often are associated with greater distance to sources of colonization (e.g., Larned et al. 2011) and dry hyporheic sediments (e.g., Boulton 2003, Datry 2012). Therefore, the effects of channel drying on communities may differ depending on the duration of drying events (Lake 2003, Datry et al. 2014a).

We addressed the effects of flow intermittence on taxonomic richness, composition, and functional diversity of aquatic invertebrate communities across 8 BRs in southeastern France. We used a multisite Before-After-ControlImpact design to quantify the effects of drying events of different durations (moderate: $2-3 \mathrm{wk}$, severe: $1-3 \mathrm{mo}$ ) on these communities. We predicted that moderate drying events would have no detectable effects on communities because taxa are frequently exposed to multiple disturbances and, therefore, have strategies that promote their resistance and resilience. Moreover, we predicted that severe drying events would alter communities because resistance and resilience strategies of taxa will be less effective as channel drying becomes exacerbated and the availability of refuges, including saturated hyporheic sediments, decreases with increased drying duration.

\section{METHODS \\ Braided rivers and study reaches}

We studied 8 BRs in southeastern France, a region that contains a high concentration of BRs in the Alps (Fig. 1, Table 1; Piégay et al. 2009). These rivers are influenced or dominated by a Mediterranean climate, including mild, rainy springs and hot, dry summers (Piégay et al. 2009). Flow regimes in Mediterranean rivers are characterized by floods and drying events that are more stochastic, frequent, and intense than those in rivers in temperate climate zones (Bonada et al. 2007). For example, in addition to frequent summer drying events, BRs in this region had up to 28 overbank flood events between 1990 and 2000 (Belletti et al. 2014).

The focal BRs are 17 to $74 \mathrm{~km}$ (mean \pm SD, $39 \pm 21 \mathrm{~km}$ ) in length, with catchment areas from 112 and $612 \mathrm{~km}^{2}$ (326 $\left.\pm 171 \mathrm{~km}^{2}\right)$, and have mean annual discharge from 1.3 to $3.2 \mathrm{~m}^{3} / \mathrm{s}\left(2.1 \pm 0.7 \mathrm{~m}^{3} / \mathrm{s}\right)$ (Table 1$)$. For each river, we selected an intermittent reach that underwent drying during the study period (May-November 2011) and a 


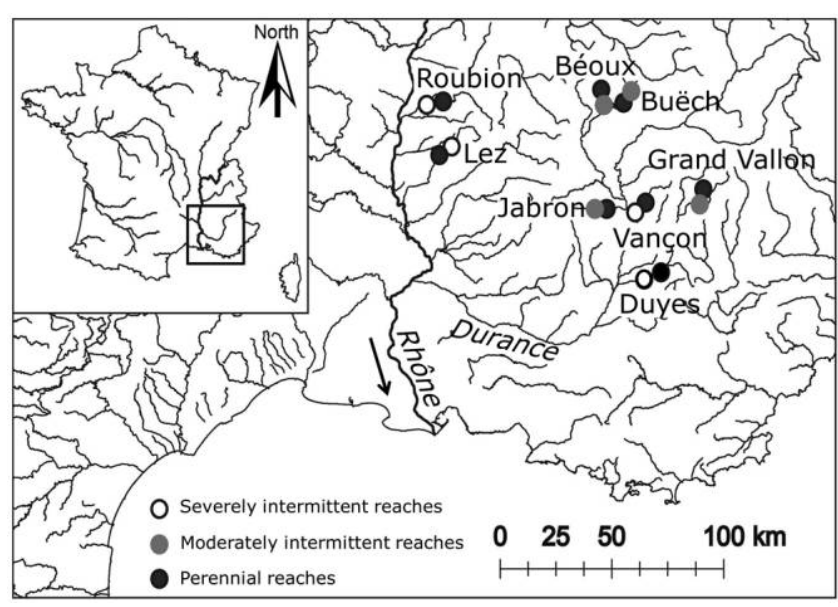

Figure 1. Location of the intermittent and perennial reaches across 8 gravel-bed, braided rivers in southeastern France.

nearby perennial reach that flowed throughout the study period (Fig. 1, Table 1). We selected reaches based on observations from previous studies (Capderrey et al. 2013), aerial photographs (www.geoportail.fr), and preliminary field visits. Intermittent reaches were in downwelling areas, typically characterized by a wide and active braided band and a large valley bottom (Capderrey et al. 2013). At these reaches, surface water was completely absent during drying events and disconnected pools persisted only for $\leq 1-2$ $\mathrm{d}$ because of high hydraulic conductivity of the river bed.
Perennial reaches were upstream $(n=3)$ or downstream $(n=5)$ of the intermittent reaches (mean distance $=2.4 \pm$ $1.8 \mathrm{~km}$; Table 1) in areas with narrow active braided channels and valley bottoms (Fig. 1). In all rivers, segments with perennial flow were present upstream of intermittent study reaches. The active braided channel was 12-278 m wide $(78 \pm 65 \mathrm{~m})$, whereas the mean wetted width of study reaches, measured before and after drying, was 1-6 m (Table 1).

\section{Quantification of flow intermittence}

At each reach, we continuously monitored the presence or absence of surface water from 4 May to 1 December 2011 using Onset Hobo ${ }^{\circledR}$ water state loggers (Intermountain Environmental, Inc., Logan, Utah). The loggers consisted of a water state data logger, submersible case, coated cable (length $=10 \mathrm{~m}$ ), and water presence sensor. A detailed description of the loggers and their installation are provided in Appendix S1.

\section{Invertebrate community sampling}

We collected benthic invertebrates from each reach in 2 sampling periods, spring (4-12 May 2011) and autumn (21-30 November 2011), which occurred before ( $\geq 5 \mathrm{~d})$ and after ( $\geq 19$ d) summer drying events, respectively. At each reach, we selected 3 runs to minimize betweenhabitat variability among reaches, including the $1-3$ runs at which loggers had been installed. Within each run, we

Table 1. Mean annual discharge, river length, distance between reaches, active channel width, and reach width across 8 braided rivers that experienced moderate or severe drying events.

\begin{tabular}{|c|c|c|c|c|c|c|c|c|c|}
\hline $\begin{array}{l}\text { Drying } \\
\text { class }\end{array}$ & River & Reach type & $\begin{array}{l}\text { Catchment } \\
\text { area }\left(\mathrm{km}^{2}\right)\end{array}$ & $\begin{array}{c}\text { Annual } \\
\text { discharge } \\
\left(\mathrm{m}^{3} / \mathrm{s}\right)\end{array}$ & $\begin{array}{l}\text { River length } \\
\quad(\mathrm{km})\end{array}$ & $\begin{array}{l}\text { Distance } \\
\text { between } \\
\text { reaches } \\
(\mathrm{km})\end{array}$ & $\begin{array}{l}\text { Elevation } \\
\quad(\mathrm{m})\end{array}$ & $\begin{array}{c}\text { Active } \\
\text { channel } \\
\text { width }(\mathrm{m})\end{array}$ & $\begin{array}{c}\text { Wetted } \\
\text { reach } \\
\text { width }(\mathrm{m})\end{array}$ \\
\hline \multirow[t]{8}{*}{ Moderate } & Béoux & Intermittent & 389 & - & 17.3 & 2.2 & 874 & 141 & $4-5$ \\
\hline & & Perennial & & & & & 923 & 31 & $4-5$ \\
\hline & Buëch & Intermittent & 389 & 2.1 & 44.5 & 2.8 & 895 & 98 & $3-5$ \\
\hline & & Perennial & & & & & 869 & 70 & $3-5$ \\
\hline & Grand Vallon & Intermittent & 332 & - & 19.2 & 0.7 & 638 & 42 & $1-2$ \\
\hline & & Perennial & & & & & 626 & 58 & $1-2$ \\
\hline & Jabron & Intermittent & 205 & 3.2 & 36.5 & 5.8 & 482 & 278 & $5-6$ \\
\hline & & Perennial & & & & & 462 & 61 & $5-6$ \\
\hline \multirow[t]{8}{*}{ Severe } & Duyes & Intermittent & 124 & 1.9 & 25.2 & 1.8 & 396 & 37 & $2-5$ \\
\hline & & Perennial & & & & & 515 & 47 & $2-5$ \\
\hline & Lez & Intermittent & 445 & 1.3 & 73.5 & 4.0 & 208 & 77 & $3-4$ \\
\hline & & Perennial & & & & & 178 & 77 & $2-3$ \\
\hline & Roubion & Intermittent & 612 & 1.9 & 66.0 & 1.2 & 190 & 30 & $2-5$ \\
\hline & & Perennial & & & & & 187 & 12 & $2-5$ \\
\hline & Vançon & Intermittent & 112 & - & 30.2 & 0.3 & 466 & 140 & $2-5$ \\
\hline & & Perennial & & & & & 468 & 51 & $3-5$ \\
\hline
\end{tabular}


randomly collected 2 benthic invertebrate samples with a Hess sampler (diameter $=40 \mathrm{~cm}$, area $=0.125 \mathrm{~m}^{2}, 200-\mu \mathrm{m}$ mesh) for a total of 192 samples (6 samples/reach $\times 2$ reaches/river $\times 8$ rivers $\times 2$ sampling periods). We preserved samples with $96 \%$ ethanol and counted and identified all invertebrates to the lowest practical taxonomic level in the laboratory. We identified all mollusks and most insects to the level of genus and crustaceans, annelids, and mites to the level of genus, family, or order.

\section{Data analysis}

Quantification of flow intermittence across reaches For each run where loggers were installed, we quantified flow intermittence based on total number ( $n$, events), total duration $\left(D_{\text {total }}\right)$, mean duration $\left(D_{\text {mean }}\right)$, and maximum duration $\left(D_{\max }\right)$ of drying events during the period of record. We also calculated the length of time before the first drying event $\left(\mathrm{T}_{\text {before }}\right)$ and the length of time after the last drying event $\left(\mathrm{T}_{\mathrm{after}}\right)$, relative to the date that invertebrate samples were collected in spring and autumn, respectively. These data confirmed our initial assignment of reaches into intermittent and perennial reach types. We then assigned intermittent reaches into 2 drying classes: moderate drying ( $n=4$ reaches) when $D_{\max }$ was $<1$ mo and severe drying $\left(n=4\right.$ reaches) when $D_{\max }$ was $>1$ mo. We chose $D_{\max }$ to categorize drying severity because it represents the longest continuous drying event experienced by aquatic invertebrate communities during the study period, which sometimes included multiple brief periods (1-2 d) of flow resumption. These 2 drying classes represent drying events in the focal study and do not necessarily match the severity of drying in other types of intermittent rivers (i.e., desert, karstic, polar), where drying events can be longer.

Effects of flow intermittence on taxonomic richness and composition of invertebrate communities We described invertebrate communities at each reach and for each period in terms of taxonomic richness, density (individuals [ind] $/ \mathrm{m}^{2}$ ), and the proportions (\% relative abundance) of EPT (Ephemeroptera, Plecoptera, Trichoptera) and OCHD (Odonata, Coleoptera, Heteroptera, Diptera). The latter 2 metrics commonly change in response to drying events because a shift occurs from lotic (mostly preferred by EPT) to lentic (mostly preferred by OCHD) habitat types, which usually precedes complete channel drying (e.g., Bonada et al. 2006, Williams 2006). These metrics were used as dependent variables in linear mixed-effects models with Gaussian error distribution. Density was $\log _{10}(x+1)$ transformed, and proportion data were $\arcsin \sqrt{ }(x)$-transformed to meet the assumptions of parametric analysis. For each dependent variable, models included 2 sampling periods (before and after drying events), 2 reach types (intermit- tent, perennial), and the interaction term (reach type $\times$ sampling period) as categorical fixed factors and river as a random factor (Bolker et al. 2009). We used the significance of the interaction term $(p<0.05)$ to identify a significant effect of drying. We analyzed invertebrate data from moderate $(n=4)$ and severe $(n=4)$ reaches separately. We constructed all linear mixed-effects models using $\mathrm{R}$ software (version 2.8.1; R Project for Statistical Computing, Vienna, Austria) nlme package (Pinheiro et al. 2014). We calculated effect size and 95\% confidence intervals for each richness and composition metric across reach types, regardless of sampling period, for both drying classes (Table S1 in Appendix S2).

We used Adonis, a permutational multivariate analysis of variances (Anderson 2001), to test for the effects of reach type, sampling period, and their interaction on multivariate taxonomic composition. Adonis returns a $R^{2}$ statistic that is a measure of separation among groups (0 indicates complete mixing and 1 represents full separation) according to Bray-Curtis dissimilarity values calculated using $\log _{10}(x+1)$-transformed invertebrate abundance and a $p$-value estimated by repeated permutations $(n=999)$ of the data. The design included 2 sampling periods (before, after) and 2 reach types (intermittent, perennial) and used river as random factor. We performed Adonis separately for both drying classes.

We used nonmetric multidimensional scaling (NMDS) to visualize compositional changes in invertebrate communities among reach types and sampling periods. First, we calculated dissimilarity matrices by means of the BrayCurtis dissimilarity index from the mean $\log _{10}(x+1)$ transformed invertebrate abundance by sampling period and reach type. Second, we used Procrustes to display spatial ordinations (between reach) across before and after sampling periods. Procrustes uses uniform scaling (expansion or contraction) and rotation to minimize the squared differences between 2 ordinations (Peres-Neto and Jackson 2001). Within each drying class, the ordinations of all reaches according to their taxonomic composition are shown simultaneously, and for each reach, arrows join their respective positions between sampling periods. We performed NMDS, Procrustes, and Adonis statistical procedures with functions in the $\mathrm{R}$ package vegan (Oksanen et al. 2013).

\section{Effects of flow intermittence on functional diversity, trait richness, and composition of invertebrate communities}

We compared Rao's quadratic entropy (i.e., functional diversity), trait richness, and composition between sampling periods and reach types. Rao's quadratic entropy is an abundance-weighted metric that measures the mean pairwise dissimilarities of randomly selected taxa in a community as a way of describing the breadth of traits present within a community (Rao 1982). Trait richness is 
measured as the total number of traits represented within the community. Generally, these 2 metrics serve as a proxy of the different ecological roles (i.e., functions) that taxa play in an ecosystem and respond to changes in trait composition (Heino 2005). For these metrics, we characterized invertebrate communities based on 61 traits representing 8 grouping features: aquatic stage, reproduction, dispersal, resistance form, food, feeding style, respiration, and locomotion and substratum relation (Appendix S3; Tachet et al. 2002, Schmera et al. 2015). Trait information was unavailable for 28 of the 105 unique taxa identified, mostly among the Diptera, Mollusca, Coleoptera, and Heteroptera. Therefore, we excluded these taxa from analysis of functional diversity, trait richness, and composition analysis. We used a trait database that is fuzzy coded (scores $0-5$ ) according to the affinity of each genus to a particular trait (Tachet et al. 2002). We weighted each trait by multiplying the relative trait affinity scores by the $\log _{10}$ $(x+1)$-transformed abundance of each taxon with the trait and dividing this value by the total abundance for each sample, which resulted in a trait $\times$ sample matrix (Dray and Dufour 2007). We used this matrix to calculate functional diversity and trait richness in the $\mathrm{R}$ packages ade4 and vegan, respectively (Dray and Dufour 2007, Oksanen et al. 2013). We further tested for changes in trait composition with the trait $\times$ sample matrix by means of Adonis as described previously.

We also selected a priori a group of traits, identified as indicators of flow intermittence and active use of the hyporheic zone as a refuge, to test the effects of drying on trait composition (Bonada et al. 2007, Robertson and Wood 2010). These traits included resistance forms (i.e., eggs, statoblasts, cocoons, diapause, and desiccation resistant cells), small body size $(\leq 9 \mathrm{~mm})$, active aerial dispersion, swimmer habit, burrower or interstitial habit, aerial respiration, and asexual reproduction. We used the $R$ package ade4 (Dray and Dufour 2007) to calculate the proportion of taxa in each sample that had the a priori traits. We then tested for the effects of drying on each $\arcsin \sqrt{ }(x)$-transformed trait proportion by means of linear mixed-effects models, as described above, where the proportional values for each trait were used as dependent variables and moderate and severe drying classes were analyzed in separate models. We calculated effect sizes and $95 \%$ confidence intervals of functional diversity, trait richness, and composition metrics as described above for the taxonomic metrics (Appendix S2).

\section{RESULTS}

\section{Quantification of flow intermittence across reaches}

The moderate reaches underwent $11 \pm 8$ (mean \pm SD) drying events, lasting a total of $43 \pm 55 \mathrm{~d}\left(\mathrm{D}_{\text {total }}\right)$, with $D_{\text {mean }}=5 \pm 3 \mathrm{~d}$ and $D_{\max }=17 \pm 4 \mathrm{~d}$ (Table 2). The severe reaches underwent $8 \pm 5$ drying events, lasting a total of $104 \pm 45 \mathrm{~d}\left(\mathrm{D}_{\text {total }}\right)$, with $\mathrm{D}_{\text {mean }}=24 \pm 19 \mathrm{~d}$ and $\mathrm{D}_{\max }=57 \pm 35 \mathrm{~d}$. Length of time after the final drying event $\left(\mathrm{T}_{\mathrm{after}}\right)$ was $25 \pm 5 \mathrm{~d}$ at severe reaches and $81 \pm$ $60 \mathrm{~d}$ at moderate reaches (Table 2).

\section{Effects of flow intermittence on taxonomic richness and} composition of invertebrate communities

A total of 74,143 invertebrates from 105 taxa was collected from the 8 BRs. Mean density of invertebrates was $2513 \pm 3356 \mathrm{ind} / \mathrm{m}^{2}$ in intermittent and $3635 \pm 4921 \mathrm{ind} /$ $\mathrm{m}^{2}$ in perennial reaches. No reach type $\times$ sampling period interactive effect was detected when comparing taxonomic richness, density, or the proportion of EPT and OCHD between moderate and severe reaches (Fig. 2A-H, Table 3). Taxonomic richness and density decreased, respectively, over the sampling period by $46 \pm 24$ and $82 \pm$ $12 \%$ in perennial reaches, $64 \pm 20$ and $96 \pm 5 \%$ in moderate reaches, and $49 \pm 27$ and $72 \pm 15 \%$ in severe reaches (Fig. 2A-D, Table 3). Proportions of EPT and OCHD did not differ among reach types or sampling periods (Fig. 2E-H, Table 3).

Community composition showed no effects of drying events among reaches and sampling periods, regardless of duration (Adonis, reach type $\times$ sampling period interaction, moderate: $p=0.772$, severe: $p=0.936$; Fig. 3A, B). Temporal variability in taxonomic composition (i.e., before-after differences) was high (Adonis, sampling period, moderate: $p=0.003$, severe: $p=0.005)$ and consistent across reach types (Fig. 3A, B).

\section{Effects of flow intermittence on functional diversity, trait richness, and composition of invertebrate communities}

Flow intermittence did not affect functional diversity, trait richness, or composition (Fig. 4A-H, Table 4). No interactive effect of sampling period $\times$ reach type was detected when comparing functional diversity and trait richness between moderate and severe reaches (Fig. 4A-D, Table 4). Trait composition among reaches was unaffected by drying events, regardless of drying class (Adonis, moderate: reach type $\times$ sampling period interaction, $p=0.663$, severe: $p=0.795)$. Furthermore, no interactive effect of reach type $\times$ sampling period was detected on resistance forms (Fig. 4E, F, Table 4), small body size ( $\leq 9 \mathrm{~mm}$; Fig. 4G, $\mathrm{H}$, Table 4), active aerial dispersion, swimmer habit, burrower or interstitial habit, aerial respiration, or asexual reproduction (data not shown) (linear mixed-effects models, $p>0.05)$.

\section{DISCUSSION}

Invertebrate communities in these 8 BRs were highly resilient to flow intermittence, even after severe drying events. Taxonomic richness, composition, and functional 
Table 2. Description of moderate and severe drying events across 8 gravel-bed, braided rivers in terms of total number ( $n$, events), total duration $\left(D_{\text {total }}\right)$, mean duration $\left(D_{\text {mean }}\right)$, and maximum duration $\left(D_{\max }\right)$ of drying events, length of time before initial drying event $\left(\mathrm{T}_{\text {before }}\right)$, and length of time after final drying event $\left(\mathrm{T}_{\text {after }}\right)$.

\begin{tabular}{|c|c|c|c|c|c|c|c|c|}
\hline Drying class & River & Reach type & $n$ (events) & $\mathrm{D}_{\text {total }}(\mathrm{d})$ & $\mathrm{D}_{\text {mean }}(\mathrm{d})$ & $\mathrm{D}_{\max }(\mathrm{d})$ & $\mathrm{T}_{\text {before }}(\mathrm{d})$ & $\mathrm{T}_{\mathrm{after}}(\mathrm{d})$ \\
\hline \multirow[t]{8}{*}{ Moderate } & Béoux & Intermittent & 4 & 18 & 4.5 & 16 & 52 & 133 \\
\hline & & Perennial & \multicolumn{6}{|c|}{ No drying events } \\
\hline & Buëch & Intermittent & 15 & 125 & 8.3 & 23 & 5 & 28 \\
\hline & & Perennial & \multicolumn{6}{|c|}{ No drying events } \\
\hline & Grand Vallon & Intermittent & 20 & 12 & 1.4 & 14 & 70 & 30 \\
\hline & & Perennial & \multicolumn{6}{|c|}{ No drying events } \\
\hline & Jabron & Intermittent & 3 & 15 & 5.1 & 14 & 52 & 134 \\
\hline & & Perennial & \multicolumn{6}{|c|}{ No drying events } \\
\hline \multirow[t]{8}{*}{ Severe } & Duyes & Intermittent & 7 & 72 & 10.2 & 34 & 92 & 30 \\
\hline & & Perennial & \multicolumn{6}{|c|}{ No drying events } \\
\hline & Lez & Intermittent & 15 & 59 & 9.1 & 30 & 25 & 26 \\
\hline & & Perennial & \multicolumn{6}{|c|}{ No drying events } \\
\hline & Roubion & Intermittent & 5 & 132 & 26.5 & 105 & 43 & 26 \\
\hline & & Perennial & \multicolumn{6}{|c|}{ No drying events } \\
\hline & Vançon & Intermittent & 3 & 152 & 50.7 & 60 & 25 & 19 \\
\hline & & Perennial & \multicolumn{6}{|c|}{ No drying events } \\
\hline
\end{tabular}

diversity of communities in intermittent reaches after either moderate or severe drying events were similar to those of perennial reaches in as few as $19 \mathrm{~d}$ of flow resumption. These results differ from those of many previous studies in which aquatic communities showed persistent effects of flow intermittence (e.g., del Rosario and Resh 2000, Bogan et al. 2013, Datry et al. 2014a). We attribute these results to: 1 ) high resilience of invertebrate communities in BRs, whose constituent taxa have been filtered by deterministic process (i.e., niche selection) and may have positive cotolerance to multiple disturbances, and 2) the presence of perennial habitat features, including an expansive hyporheic zone, in which taxa can find refuge during drying events.

\section{Response of invertebrate communities to flow intermittence in BRs}

Flow intermittence is considered a primary driver of community structure and composition in rivers (Arscott et al. 2010, Larned et al. 2010, Datry et al. 2014b). In a broad-scale meta-analysis, Datry et al. (2014a) found that taxonomic richness decreased linearly along gradients of flow intermittence, without considering sampling period, in 14 rivers in Europe, North America, and New Zealand. Moreover, strong differences in taxonomic richness and density (see Appendix S2 for effect sizes) generally are found between perennial reaches and reaches experiencing 2-15 mo of channel drying (e.g., del Rosario and Resh
2000, Price et al. 2003, Santos and Stevenson 2011, Bogan et al. 2013). Nevertheless, we found no differences in taxonomic richness and density between intermittent and perennial reaches across these 8 BRs. Furthermore, the mean effect sizes (Hedges' $d$ ) in our study were $8 \times$ smaller than those found in previous studies (mean $=-0.25 \pm 0.3 \mathrm{vs}$ $-1.96 \pm 1.16$ ), where communities in intermittent reaches had lower taxonomic richness and density than perennial reaches, even after 2 mo of flow resumption (Appendix S2). Our results were consistent after both moderate and severe drying events, despite a $>3$-fold increase in the maximum duration of drying events (mean $D_{\max }=16$ vs $57 \mathrm{~d}$ ). Decreases in taxonomic richness and density that occurred over the sampling period were observed across both intermittent and perennial reaches and, therefore, could not be attributed to flow intermittence. Field observations (see Methods) and examination of continuous flow data for the 3 BRs where flow gauging stations were colocated (Buëch, Lez, Roubion) indicated that no high-flow events (i.e., higher than the mean annual discharge) occurred between rewetting and the after-drying sampling period. Rather, such decreases may illustrate the background of seasonal variability in invertebrate richness and density that is common in BRs (Tockner et al. 2010).

Functional diversity and trait composition also can be affected by drying events in freshwater ecosystems (Bonada et al. 2007, Chase 2007). In general, higher proportions of taxa with resistance and resilience traits are found after drying than before and in intermittent vs perennial rivers, 
Moderate
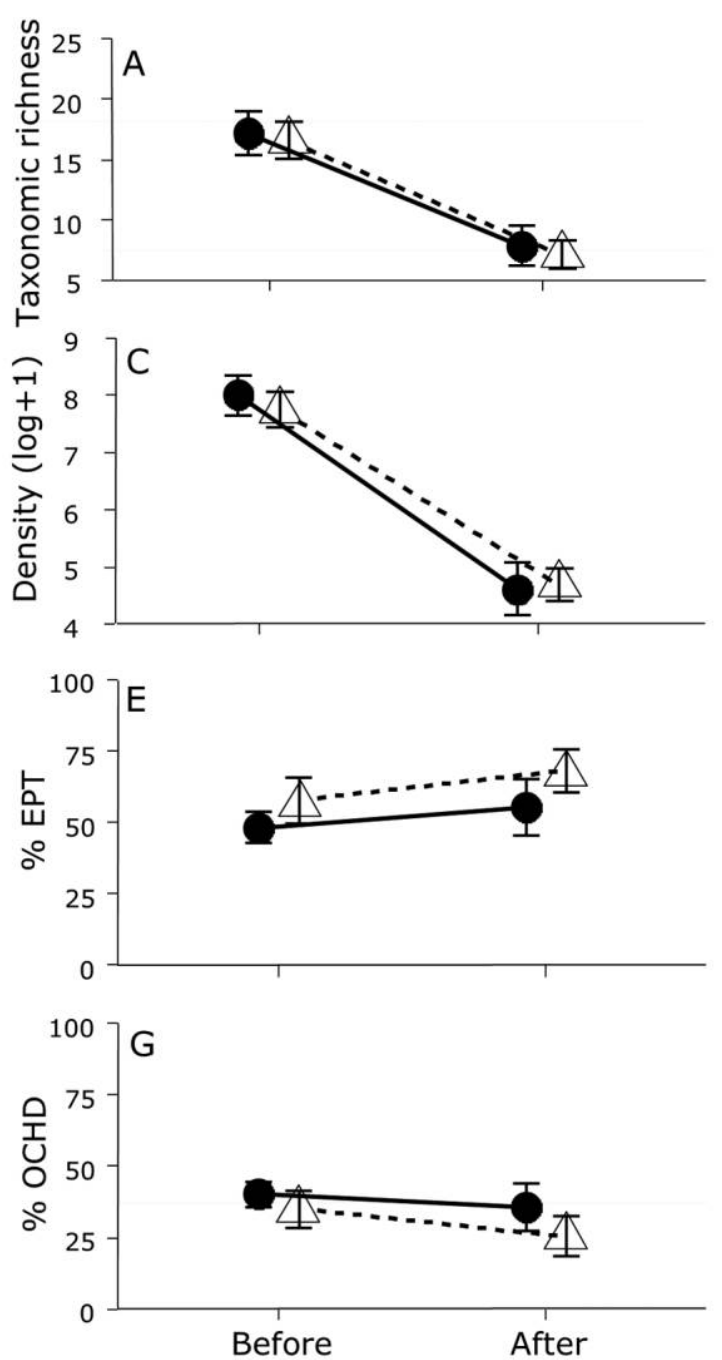

Severe
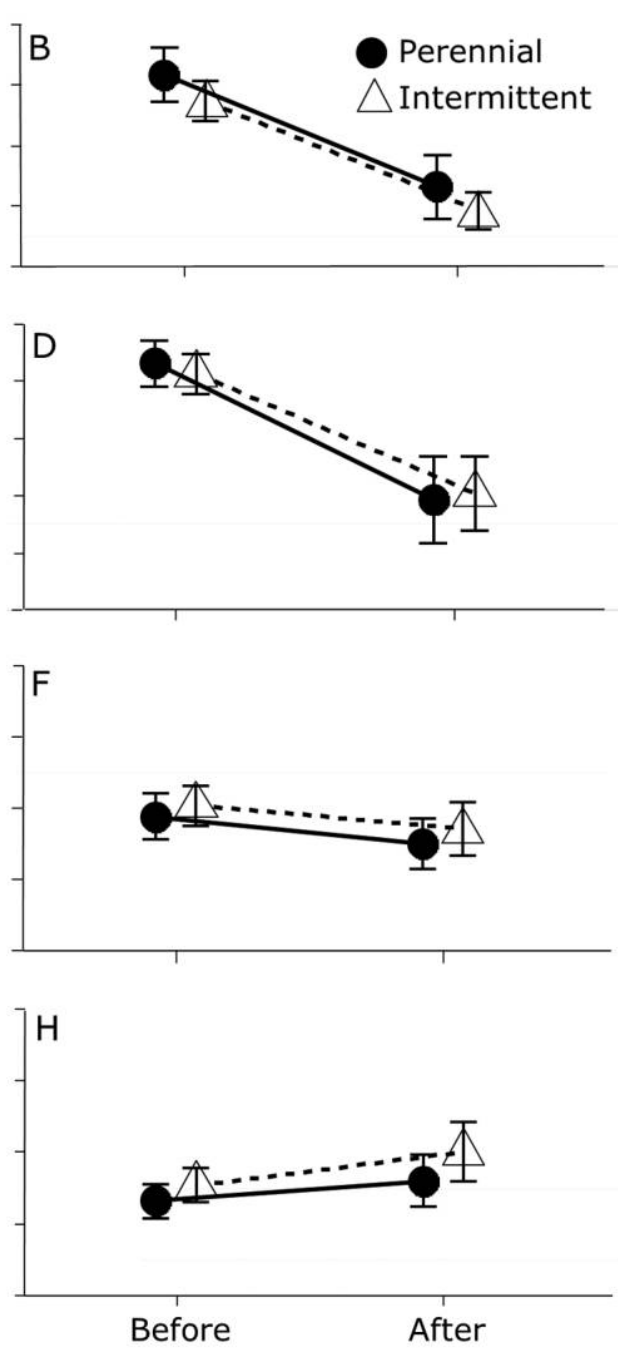

Figure 2. Interaction plots showing change from before to after drying of mean $( \pm 1 \mathrm{SE})$ taxonomic richness $(\mathrm{A}, \mathrm{B})$, $\log _{10}(x+1)$-transformed density (individuals $\left./ \mathrm{m}^{2}\right)(\mathrm{C}, \mathrm{D})$, \% EPT (Ephemeroptera, Plecoptera, Trichoptera) (E, F), and \% OCHD (Odonata, Coleoptera, Hemiptera, Diptera) $(\mathrm{G}, \mathrm{H})$ in reaches with moderate (A, C, E, G) and severe (B, D, F, H) drying.

indicating that these traits promote the persistence of invertebrate communities in habitats exposed to drying (Bonada et al. 2006, Datry et al. 2014a). The loss of taxa without these traits after drying may lead to decreases in functional diversity. For example, Chase (2007) found that pond drying reduced the diversity of producers (macrophytes and filamentous green algae) because many of these taxa lacked resistance or resilience strategies. In contrast to these studies, we found no decrease in functional diversity or changes in trait composition following drying events, despite a temporal decrease in taxonomic richness. This result indicates that communities in these BRs have functional redundancy, which occurs when different taxa play similar roles in an ecosystem or possess similar traits but may have different sensitivity to disturbances (Rosenfeld 2002). As in arid-land systems (e.g., Boersma et al. 2014), high functional redundancy in BRs may provide insurance against the loss of ecosystem functions when faced with disturbances.

The resilience of invertebrate communities after drying events is comparatively higher in BRs than other intermittent rivers. In our study, recovery occurred in as few as $19 \mathrm{~d}$ following severe drying events. Fowler (2004) found that $95 \%$ of pre-drying taxa were present after $7 \mathrm{~d}$ of rewetting in 2 braided rivers in New Zealand that dried for 6-14 wk. In contrast, Delucchi (1988) reported that $50 \%$ of pre-drying taxa remained lost or had reduced abundances after $\geq 1$ mo of rewetting in small-medium 
Table 3. Linear mixed-effects models testing the effects of sampling period (before vs after), reach type (perennial vs intermittent), and their interaction on taxonomic richness, $\log _{10}(x+1)$-transformed density (individuals $/ \mathrm{m}^{2}$ ), and the $\arcsin \sqrt{ }(x)$-transformed \% EPT (Ephemeroptera, Plecoptera, Trichoptera) and \% OCHD (Odonata, Coleoptera, Hemiptera, Diptera).

\begin{tabular}{|c|c|c|c|c|c|}
\hline Drying class & Variable & Source of variation & $\mathrm{df}$ & $F$ & $p$ \\
\hline \multirow[t]{16}{*}{ Moderate } & \multirow[t]{4}{*}{ Taxonomic richness } & Intercept & 80 & 39.95 & $<0.0001$ \\
\hline & & Sampling period & 6 & 82.87 & $<0.0001$ \\
\hline & & Reach type & 3 & 0.69 & 0.4683 \\
\hline & & Reach $\times$ period & 6 & 1.52 & 0.2643 \\
\hline & \multirow[t]{4}{*}{ Density } & Intercept & 80 & 170.69 & $<0.0001$ \\
\hline & & Sampling period & 6 & 158.24 & $<0.0001$ \\
\hline & & Reach type & 3 & 2.35 & 0.2226 \\
\hline & & Reach $\times$ period & 6 & 1.27 & 0.3020 \\
\hline & \multirow[t]{4}{*}{$\% \mathrm{EPT}$} & Intercept & 80 & 56.46 & $<0.0001$ \\
\hline & & Sampling period & 6 & 3.89 & 0.0961 \\
\hline & & Reach type & 3 & 5.76 & 0.0959 \\
\hline & & Reach $\times$ period & 6 & 1.10 & 0.3347 \\
\hline & \multirow[t]{4}{*}{$\%$ OCHD } & Intercept & 80 & 34.48 & $<0.0001$ \\
\hline & & Sampling period & 6 & 4.16 & 0.0874 \\
\hline & & Reach type & 3 & 3.05 & 0.1790 \\
\hline & & Reach $\times$ period & 6 & 0.70 & 0.4352 \\
\hline \multirow[t]{16}{*}{ Severe } & \multirow[t]{4}{*}{ Taxonomic richness } & Intercept & 80 & 29.3 & $<0.0001$ \\
\hline & & Sampling period & 6 & 18.98 & 0.0048 \\
\hline & & Reach type & 3 & 0.94 & 0.4035 \\
\hline & & Reach $\times$ period & 6 & 0.01 & 0.9546 \\
\hline & \multirow[t]{4}{*}{ Density } & Intercept & 80 & 64.01 & $<0.0001$ \\
\hline & & Sampling period & 6 & 22.54 & 0.0032 \\
\hline & & Reach type & 3 & 0.01 & 0.9324 \\
\hline & & Reach $\times$ period & 6 & 0.09 & 0.7768 \\
\hline & \multirow[t]{4}{*}{$\% \mathrm{EPT}$} & Intercept & 80 & 27.34 & $<0.0001$ \\
\hline & & Sampling period & 6 & 3.63 & 0.1054 \\
\hline & & Reach type & 3 & 0.83 & 0.4304 \\
\hline & & Reach $\times$ period & 6 & $<0.00$ & 0.9841 \\
\hline & \multirow[t]{4}{*}{$\% \mathrm{OCHD}$} & Intercept & 80 & 38.48 & $<0.0001$ \\
\hline & & Sampling period & 6 & 0.71 & 0.4332 \\
\hline & & Reach type & 3 & 0.36 & 0.5890 \\
\hline & & Reach $\times$ period & 6 & 0.04 & 0.8468 \\
\hline
\end{tabular}

forested streams that experienced 1-4-mo drying events. Morrison (1990) reported that recovery of taxonomic richness and abundance took $\geq 2$ mo after 2-3-mo drying events in 4 small streams in Scotland. Most drastically, drying (2-6 mo) had persistent effects on community composition that lasted 1-2 y (Wood and Armitage 2004, Acuña et al. 2005). Other investigators showed that invertebrate communities also may be more resilient to floods in BRs compared with other rivers (Matthaei et al. 1996). Thus, the effects of flow intermittence on invertebrate communities may vary strongly according to river type, and further comparisons may help unravel underlying processes that mitigate these effects of drying.

\section{Factors that might promote community resilience and functional redundancy in BRs}

High resilience and functional redundancy in BRs may be first explained by a strong filtering (i.e., niche selection) of taxa from the regional species pool with traits allowing them to cope with multiple disturbances (i.e., resistance and resilience; Poff and Ward 1990, Lytle and Poff 2004). When traits enable resistance and resilience 

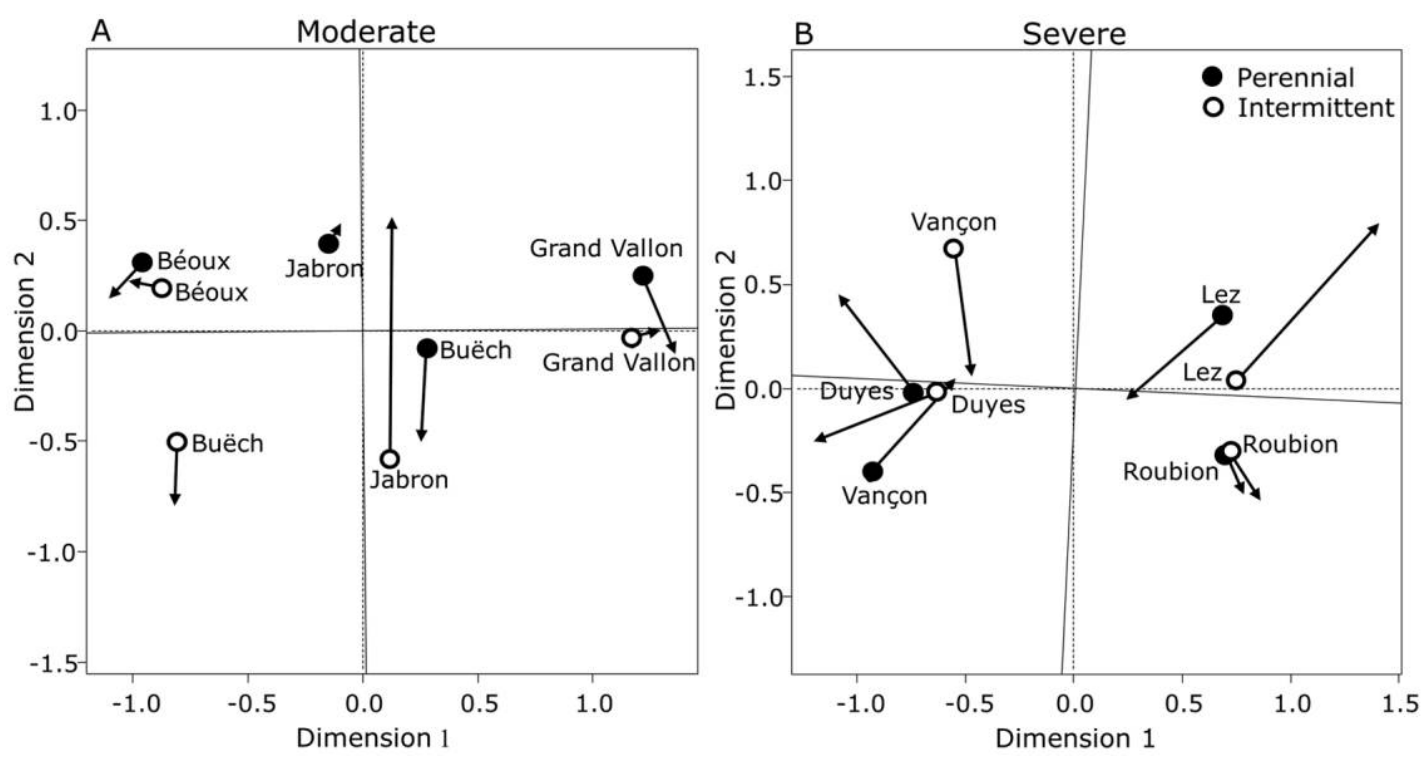

Figure 3. Two-dimensional nonmetric multidimensional scaling (NMDS) plots with Procrustes superimposition based on $\log _{10}(x+1)$-transformed density of invertebrates in reaches with moderate (A) and severe (B) drying. Arrows represent the differences in ordinations between the before (origin of the arrows) and after sampling periods (end of the arrows).

of communities to multiple disturbance types, community resilience to a discrete disturbance event is increased (i.e., positive cotolerance; Vinebrooke et al. 2004). For instance, some resilience strategies that allow taxa to disperse to and from refuges during and after floods, including high dispersal ability, inherently promote the recovery of communities after channel drying. Some resistance strategies, such as aerial respiration, allow invertebrates to remain in dry channels until water returns but also help some taxa (e.g., Hemiptera: Belostomatidae) escape flash floods by allowing them to crawl out of the channel to survive in riparian areas (Lytle and Poff 2004). In BRs, the high recurrence rate of disturbances, such as floods and bed scouring, probably eliminates most taxa that are not also resistant or resilient to drying, thereby reducing the effect of a drying event on the community. However, not all traits that promote resistance and resilience are positively correlated across disturbance types (i.e., negative cotolerance; Vinebrooke et al. 2004). For example, taxa with strong flying ability as adults have inherently larger body size in their aquatic stages. Therefore, their ability to fly long distances to colonize previously dried channels hinders them in the aquatic stage where they are more susceptible to floods than are smaller taxa (Townsend and Hildrew 1994). These examples are far from exhaustive but highlight interesting cases of cotolerance in invertebrate taxa to multiple disturbances. Although not often considered by freshwater ecologists, we think that varying responses of freshwater communities to flow intermittence are partially at- tributable to positive cotolerance with floods and bed scouring.

A fundamental habitat feature of BRs that can promote invertebrate community resilience is the complex patterns of surface-groundwater exchanges, occurring at different scales within the often porous, alluvial river bed (Malard et al. 2003, Capderrey et al. 2013). These exchanges add habitat heterogeneity and offer potential drying refuges for invertebrates (Stanford et al. 2005, Capderrey et al. 2013). Perennial reaches, which are a source of drifting and flying invertebrate colonists, are often maintained by large-scale upwelling zones in BRs (Capderrey et al. 2013). In addition, the gravel river beds in most BRs create an expansive hyporheic zone that can be a refuge for benthic invertebrates during periods of flooding and drying (Boulton et al. 2010). However, evidence remains inconclusive for whether benthic taxa seeking refuge in hyporheic zones actually return to the surface after disturbances (but see Holomuzki and Biggs 2007). This uncertainty is a result, in part, of difficulties in quantifying the number of invertebrates that come from the hyporheic zone compared with from other sources (e.g., drift from upstream, aerial oviposition; Dole-Olivier 2011, Stubbington 2012). Recovery of communities after floods and drying occurs as a function of distance to drying refuges, which affects the colonization rate of drifting and flying invertebrates, with faster recovery corresponding to shorter distances (Fritz and Dodds 2004, Robson et al. 2011). Resilience in BRs probably is high compared with other systems because the pattern of surface-groundwater exchanges across al- 
Moderate
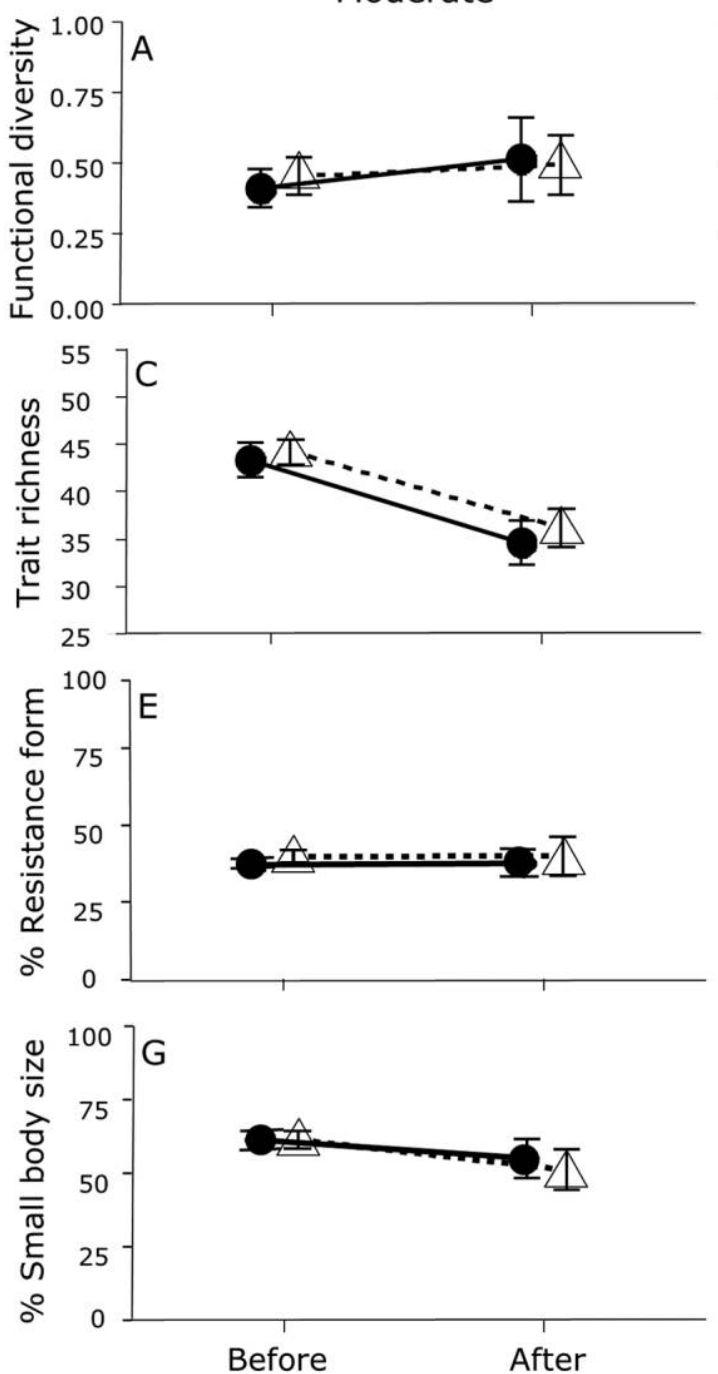
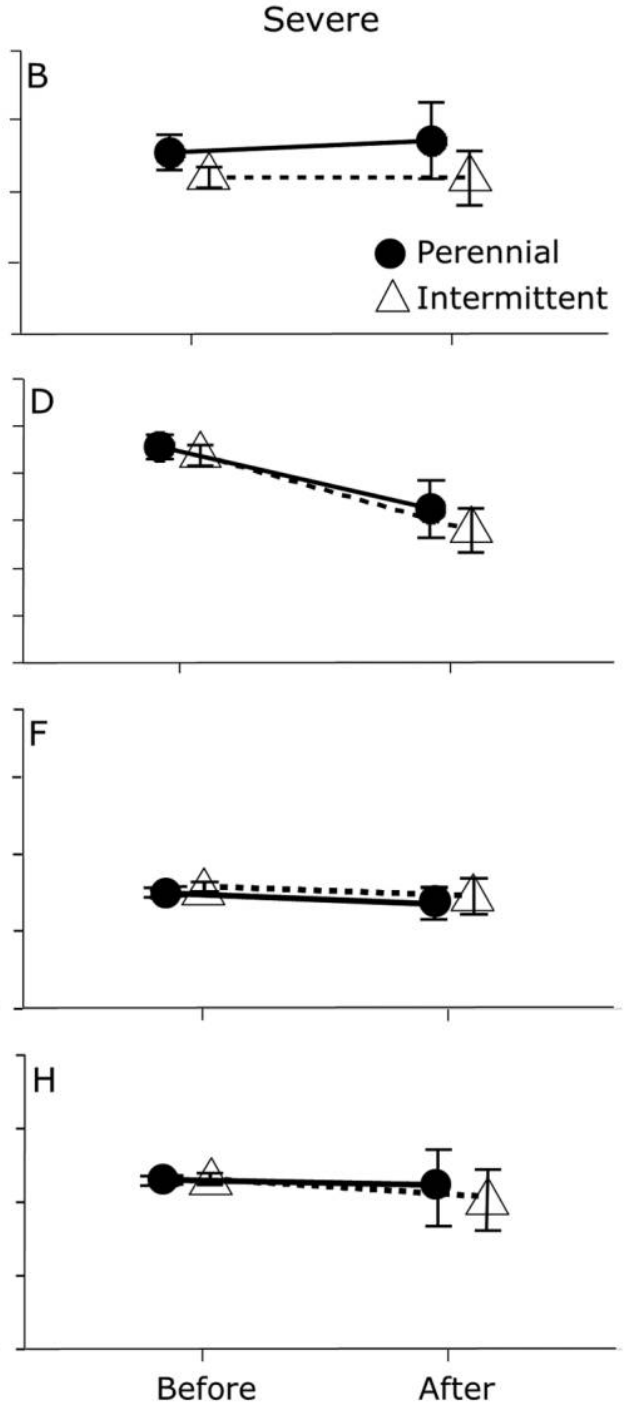

Figure 4. Interaction plots showing change from before to after drying of mean $( \pm 1$ SE) functional diversity (A, B), trait richness $(C, D)$, proportion of taxa with resistance form $(E, F)$, and small body size $(<9 \mathrm{~mm})(\mathrm{G}, \mathrm{H})$ in reaches with moderate $(A, C, E, G)$ and severe (B, D, F, H) drying.

luvial river beds provides potential sources of colonists that are found either directly below the river bed or within several kilometers $(<10 \mathrm{~km})$ upstream of previously dry channels.

\section{Conclusions}

The current understanding of how communities respond to flow intermittence lags behind other facets of freshwater ecology and merits future research emphasis (Larned et al. 2010, Datry et al. 2014b). Our results suggest that the effects of flow intermittence on invertebrate communities may vary strongly according to river type and call for a cross-system comparison to explore parallels and contrasts and to better understand processes that mitigate the response of communities to drying. As shown in marine systems, such comparisons may reveal that communities in more disturbed systems are also highly resilient because they have a high abundance of disturbance-tolerant taxa (Côté and Darling 2010). In addition, the colonization pathways upon rewetting, and notably the importance of the contribution of the hyporheic zone to community resilience, deserve more research and, above all, better quantification (Boulton et al. 2010, Dole-Olivier 2011). In the current context of climate change accompanied by increasing flow intermittence and anthropogenic stressors (Larned et al. 2010, Strayer and Dudgeon 2010), understanding and quantifying processes that contribute to ecosystem resilience are essential. Future research in naturally highly disturbed systems, such as BRs, could help to advance this 
Table 4. Linear mixed-effects models testing the effects of sampling period (before vs after), reach type (perennial vs intermittent), and their interaction on the $\arcsin \sqrt{ }(x)$-transformed proportion of taxa with resistance forms and small body size $(\leq 9 \mathrm{~mm})$, functional diversity, and trait richness.

\begin{tabular}{|c|c|c|c|c|c|}
\hline Drying class & Variable & Source of variation & $\mathrm{df}$ & $F$ & $p$ \\
\hline \multirow[t]{16}{*}{ Moderate } & \multirow[t]{4}{*}{$\%$ Resistance form } & Intercept & 80 & 495.68 & $<0.0001$ \\
\hline & & Sampling period & 6 & 0.27 & 0.6192 \\
\hline & & Reach type & 3 & 0.40 & 0.5704 \\
\hline & & Reach $\times$ period & 6 & 0.04 & 0.8412 \\
\hline & \multirow[t]{4}{*}{ \% Small body size } & Intercept & 80 & 300.39 & $<0.0001$ \\
\hline & & Sampling period & 6 & 4.45 & 0.0795 \\
\hline & & Reach type & 3 & 0.42 & 0.5650 \\
\hline & & Reach $\times$ period & 6 & 0.33 & 0.5857 \\
\hline & \multirow[t]{4}{*}{ Functional diversity } & Intercept & 79 & 27.56 & $<0.0001$ \\
\hline & & Sampling period & 6 & 0.37 & 0.5630 \\
\hline & & Reach type & 3 & 0.85 & 0.4253 \\
\hline & & Reach $\times$ Period & 6 & 1.76 & 0.2326 \\
\hline & \multirow[t]{4}{*}{ Trait richness } & Intercept & 79 & 298.13 & $<0.0001$ \\
\hline & & Sampling period & 6 & 100.25 & 0.0001 \\
\hline & & Reach type & 3 & 0.09 & 0.7885 \\
\hline & & Reach $\times$ Period & 6 & 3.60 & 0.1067 \\
\hline \multirow[t]{16}{*}{ Severe } & \multirow[t]{4}{*}{$\%$ Resistance form } & Intercept & 80 & 423.50 & $<0.0001$ \\
\hline & & Sampling period & 6 & 1.77 & 0.2315 \\
\hline & & Reach type & 3 & 0.11 & 0.7606 \\
\hline & & Reach $\times$ Period & 6 & $<0.01$ & 0.9485 \\
\hline & \multirow[t]{4}{*}{ \% Small body size } & Intercept & 80 & 458.90 & $<0.0001$ \\
\hline & & Sampling period & 6 & 0.15 & 0.7078 \\
\hline & & Reach type & 3 & 0.08 & 0.7942 \\
\hline & & Reach $\times$ period & 6 & 0.12 & 0.7408 \\
\hline & \multirow[t]{4}{*}{ Functional diversity } & Intercept & 79 & 49.76 & $<0.0001$ \\
\hline & & Sampling period & 6 & 0.03 & 0.8719 \\
\hline & & Reach type & 3 & 2.13 & 0.2406 \\
\hline & & Reach $\times$ period & 6 & 0.12 & 0.7367 \\
\hline & \multirow[t]{4}{*}{ Trait richness } & Intercept & 79 & 327.17 & $<0.0001$ \\
\hline & & Sampling period & 6 & 10.24 & 0.0186 \\
\hline & & Reach type & 3 & 0.51 & 0.5273 \\
\hline & & Reach $\times$ period & 6 & 0.12 & 0.7455 \\
\hline
\end{tabular}

understanding and improve the ability to predict the responses of communities to future environmental changes.

\section{ACKNOWLEDGEMENTS}

We thank Marie-Claude Roger, Michel Philippe, Guillaume Le Goff, Raphael Möns, and Pascal Roger for assistance in the field and laboratory. We also owe gratitude to Núria Bonada who commented on earlier drafts of this manuscript and offered advice on the analysis of invertebrate traits and functional diversity. Catherine Leigh provided great feedback and discussion during the preparation of this manuscript. We thank Associate Editor David Arscott and 2 anonymous referees for their excellent comments and suggestions. This research was conducted in the LTER (long-term ecological research) group of the ZABR (Zone Atelier Bassin du Rhône) and was funded by the French Water Agency Rhône-Mediterranée-Corse through the project "Braided Rivers".

\section{LITERATURE CITED}

$\rightarrow$ Acuña, V., I. Muñoz, A. Giorgi, M. Omella, F. Sabater, and S. Sabater. 2005. Drought and postdrought recovery cycles in an intermittent Mediterranean stream: structural and functional aspects. Journal of the North American Benthological Society 24:919-933. 
$\rightarrow$ Anderson, M. J. 2001. A new method for non-parametric multivariate analysis of variance. Austral Ecology 26:32-46.

$\rightarrow$ Arscott, D. B., S. Larned, M. R. Scarsbrook, and P. Lambert. 2010. Aquatic invertebrate community structure along an intermittence gradient: Selwyn River, New Zealand. Journal of the North American Benthological Society 29:530-545.

$\rightarrow$ Arscott, D. B., K. Tockner, D. van der Nat, and J. V. Ward. 2002. Aquatic habitat dynamics along a braided alpine river ecosystem (Tagliamento River, northeast Italy). Ecosystems 5:802-814.

$\rightarrow$ Belletti, B., S. Dufour, and H. Piégay. 2014. Regional assessment of the multi-decadal changes in braided riverscapes following large floods (example of 12 reaches in south east of France). Advances in Geosciences 37:57-71.

$\rightarrow$ Boersma, K. S., M. T. Bogan, B. A. Henrichs, and D. A. Lytle. 2014. Invertebrate assemblages of pools in arid-land streams have high functional redundancy and are resistant to severe drying. Freshwater Biology 59:491-501.

$\rightarrow$ Bogan, M. T., K. S. Boersma, and D. A. Lytle. 2013. Flow intermittency alters longitudinal patterns of invertebrate diversity and assemblage composition in an arid-land stream network. Freshwater Biology 58:1016-1028.

$\rightarrow$ Bolker, B. M., M. E. Brooks, C. J. Clark, S. W. Geange, J. R. Poulsen, M. H. H. Stevens, and J. S. S. White. 2009. Generalized linear mixed models: a practical guide for ecology and evolution. Trends in Ecology and Evolution 24:127-135.

$\rightarrow$ Bonada, N., S. Dolédec, and B. Statzner. 2007. Taxonomic and biological trait differences of stream macroinvertebrate communities between Mediterranean and temperate regions: implications for future climatic scenarios. Global Change Biology 13:1658-1671.

$\rightarrow$ Bonada, N., M. Rieradevall, N. Prat, and V. H. Resh. 2006. Benthic macroinvertebrate assemblages and macrohabitat connectivity in Mediterranean-climate streams of northern California. Journal of the North American Benthological Society 25:32-43.

$\rightarrow$ Boulton, A. J. 2003. Parallels and contrasts in the effects of drought on stream macroinvertebrate assemblages. Freshwater Biology 48:1173-1185.

$\rightarrow$ Boulton, A. J., T. Datry, T. Kasahara, M. Mutz, and J. A. Stanford. 2010. Ecology and management of the hyporheic zone: stream-groundwater interactions of running waters and their floodplains. Journal of the North American Benthological Society 29:26-40.

$\rightarrow$ Capderrey, C., T. Datry, A. Foulquier, C. Claret, and F. Malard. 2013. Invertebrate distribution across nested geomorphic features in braided-river landscapes. Freshwater Science 32: $1188-1204$.

$\rightarrow$ Chase, J. M. 2007. Drought mediates the importance of stochastic community assembly. Proceedings of the National Academy of Sciences of the United States of America 104:17430 17434.

$\rightarrow$ Côté, I. M., and E. S. Darling. 2010. Rethinking ecosystem resilience in the face of climate change. PLoS Biology 8: e1000438.

$\rightarrow$ Datry, T. 2012. Benthic and hyporheic invertebrate assemblages along a flow intermittence gradient: effects of duration of dry events. Freshwater Biology 57:563-574. $\rightarrow$ Datry, T., S. T. Larned, K. M. Fritz, M. T. Bogan, P. J. Wood, E. I. Meyer, and A. N. Santos. 2014a. Broad-scale patterns of invertebrate richness and community composition in temporary rivers: effects of flow intermittence. Ecography 37: 94-104.

Datry, T., S. T. Larned, and K. Tockner. 2014b. Intermittent rivers: a challenge for freshwater ecology. BioScience. doi:10 .1093/biosci/bit027

$\rightarrow$ del Rosario, R. B., and V. H. Resh. 2000. Invertebrates in intermittent and perennial streams: is the hyporheic zone a refuge from drying? Journal of the North American Benthological Society 19:680-696.

$\rightarrow$ Delucchi, C. M. 1988. Comparison of community structure among streams with different temporal flow regimes. Canadian Journal of Zoology 66:579-586.

$\rightarrow$ Doering, M., U. Uehlinger, A. Rotach, D. R. Schlaepfer, and K. Tockner. 2007. Ecosystem expansion and contraction dynamics along a large alpine alluvial corridor (Tagliamento River, northeast Italy). Earth Surface Processes and Landforms 32:1693-1704.

$\rightarrow$ Dole-Olivier, M. J. 2011. The hyporheic refuge hypothesis reconsidered: a review of hydrological aspects. Marine and Freshwater Research 62:1281-1302.

Dray, S., and A. B. Dufour. 2007. The ade4 package: implementing the duality diagram for ecologists. Journal of Statistical Software 22(4):1-20.

$\rightarrow$ Fowler, R. T. 2004. The recovery of benthic invertebrate communities following dewatering in two braided rivers. Hydrobiologia 523:17-28.

$\rightarrow$ Fritz, K. M., and W. K. Dodds. 2004. Resistance and resilience of macroinvertebrate assemblages to drying and flood in a tallgrass prairie stream system. Hydrobiologia 527:99-112.

$\rightarrow$ Götzenberger, L., F. de Bello, K. A. Bråthen, J. Davison, A. Dubuis, A. Guisan, J. Lepš, R. Lindborg, M. Moora, M. Pärtel, L. Pellissier, J. Pottier, P. Vittoz, K. Zobel, and M. Zobel. 2012. Ecological assembly rules in plant communities-approaches, patterns and prospects. Biological Reviews 87:111-127.

Gray, D., and J. S. Harding. 2007. Braided river ecology: a literature review of physical habitats and aquatic invertebrate communities. Science for Conservation 279. Science and Technical Publishing, Department of Conservation, Wellington, New Zealand.

$\rightarrow$ Heino, J. 2005. Functional biodiversity of macroinvertebrate assemblages along major ecological gradients of boreal headwater streams. Freshwater Biology 50:1578-1587.

$\rightarrow$ Holomuzki, J. R., and B. J. Biggs. 2007. Physical microhabitat effects on 3-dimensional spatial variability of the hydrobiid snail, Potamopyrgus antipodarum. New Zealand Journal of Marine and Freshwater Research 41:357-367.

$\rightarrow$ Lake, P. S. 2003. Ecological effects of perturbation by drought in flowing waters. Freshwater Biology 48:1161-1172.

$\rightarrow$ Larned, S. T., T. Datry, D. B. Arscott, and K. Tockner. 2010. Emerging concepts in temporary-river ecology. Freshwater Biology 55:717-738.

$\rightarrow$ Larned, S. T., J. Schmidt, T. Datry, C. P. Konrad, J. K. Dumas, and J. C. Diettrich. 2011. Longitudinal river ecohydrology: flow variation down the lengths of alluvial rivers. Ecohydrology 4:532-548. 
$\rightarrow$ Leibold, M. A., M. Holyoak, N. Mouquet, P. Amarasekare, J. M. Chase, M. F. Hoopes, R. D. Holt, J. B. Shurin, R. Law, D. Tilman, M. Loreau, and A. Gonzalez. 2004. The metacommunity concept: a framework for multi-scale community ecology. Ecology Letters 7:601-613.

$\rightarrow$ Lepori, F., and B. Malmqvist. 2009. Deterministic control on community assembly peaks at intermediate levels of disturbance. Oikos 118:471-479.

$\rightarrow$ Lytle, D. A., and N. L. Poff. 2004. Adaptation to natural flow regimes. Trends in Ecology and Evolution 19:94-100.

$\rightarrow$ Malard, F., D. Galassi, M. Lafont, S. Dolédec, and J. V. Ward. 2003. Longitudinal patterns of invertebrates in the hyporheic zone of a glacial river. Freshwater Biology 48:17091725.

$\rightarrow$ Matthaei, C., U. Uehlinger, E. Meyer, and A. Frutiger. 1996. Recolonization by benthic invertebrates after experimental disturbance in a Swiss prealpine river. Freshwater Biology 35:233-248.

$\rightarrow$ Morrison, B. 1990. Recolonisation of 4 small streams in central Scotland following drought conditions in 1984. Hydrobiologia 208:261-267.

Oksanen, J., F. Guillaume Blanchet, R. Kindt, P. Legendre, P. R. Minchin, R. B. O’Hara, G. L. Simpson, P. Solymos, M. Henry, H. Stevens, and H. Wagner. 2013. vegan: community ecology package. R package version 2.0-9. R Project for Statistical Computing, Vienna, Austria. (Available from http://cran.r -project.org/package=vegan)

$\rightarrow$ Olsen, D. A., and C. R. Townsend. 2005. Flood effects on invertebrates, sediments and particulate organic matter in the hyporheic zone of a gravel-bed stream. Freshwater Biology 50: 839-853.

$\rightarrow$ Peres-Neto, P. R., and D. A. Jackson. 2001. How well do multivariate data sets match? The advantages of a Procrustean superimposition approach over the Mantel test. Oecologia (Berlin) 129:169-178.

$\rightarrow$ Piégay, H., A. Alber, L. Slater, and L. Bourdin. 2009. Census and typology of braided rivers in the French Alps. Aquatic Sciences 71:371-388.

Pinheiro, J., D. Bates, S. DebRoy, D. Sarkar, and R Core Team. 2014. nlme: linear and nonlinear mixed effects models. R package version 3.1-118. R Project for Statistical Computing, Vienna, Austria. (Available from: http://cran.r-project .org/package $=$ nlme)

$\rightarrow$ Poff, N. L., J. D. Allan, M. B. Bain, J. R. Karr, K. L. Prestegaard, B. D. Richter, R. E. Sparks, and J. C. Stromberg. 1997. The natural flow regime. BioScience 47:769-784.

$\rightarrow$ Poff, N. L., and J. V. Ward. 1990. Physical habitat template of lotic systems: recovery in the context of historical pattern of spatiotemporal heterogeneity. Environmental Management 14 629-645.

$\rightarrow$ Price, K., A. Suski, J. McGarvie, B. Beasley, and J. S. Richardson. 2003. Communities of aquatic insects of old-growth and clearcut coastal headwater streams of varying flow persistence. Canadian Journal of Forest Research 33:1416-1432.

$\rightarrow$ Rao, C. R. 1982. Diversity and dissimilarity coefficients: a unified approach. Theoretical Population Biology 21:24-43.

$\rightarrow$ Robertson, A. L., and P. J. Wood. 2010. Ecology of the hyporheic zone: origins, current knowledge and future directions. Fun- damental and Applied Limnology - Archiv für Hydrobiologie 176:279-289.

$\rightarrow$ Robson, B. J., E. T. Chester, and C. M. Austin. 2011. Why life history information matters: drought refuges and macroinvertebrate persistence in non-perennial streams subject to a drier climate. Marine and Freshwater Research 62:801810.

$\rightarrow$ Rosenfeld, J. S. 2002. Functional redundancy in ecology and conservation. Oikos 98:156-162.

$\rightarrow$ Sagar, P. M. 1983. Invertebrate recolonisation of previously dry channels in the Rakaia River. New Zealand Journal of Marine and Freshwater Research 17:377-386.

$\rightarrow$ Santos, A. N., and R. D. Stevenson. 2011. Comparison of macroinvertebrate diversity and community structure among perennial and non-perennial headwater streams. Northeastern Naturalist 18:7-26.

Schmera, D., J. Podani, J. Heino, T. Erős, and N. L. Poff. 2015. A proposed unified terminology of species traits in stream ecology. Freshwater Science. doi:10.1086/681623

$\rightarrow$ Scrimgeour, G. J., R. J. Davidson, and J. M. Davidson. 1988. Recovery of benthic macroinvertebrate and epilithic communities following a large flood, in an unstable, braided, New Zealand river. New Zealand Journal of Marine and Freshwater Research 22:337-344.

$\rightarrow$ Southwood, T. R. E. 1988. Tactics, strategies and templets. Oikos 52:3-18.

Stanford, J., M. Lorang, and F. Hauer. 2005. The shifting habitat mosaic of river ecosystems. Verhandlungen der Internationalen Vereinigung für theoretische und angewandte Limnologie 29:123-136.

$\rightarrow$ Stanley, E. H., D. L. Buschman, A. J. Boulton, N. B. Grimm, and S. G. Fisher. 1994. Invertebrate resistance and resilience to intermittency in a desert stream. American Midland Naturalist 131:288-300.

$\rightarrow$ Statzner, B., and L. A. Bêche. 2010. Can biological invertebrate traits resolve effects of multiple stressors on running water ecosystems? Freshwater Biology 55:80-119.

$\rightarrow$ Strayer, D. L., and D. Dudgeon. 2010. Freshwater biodiversity conservation: recent progress and future challenges. Journal of the North American Benthological Society 29:344358.

$\rightarrow$ Stubbington, R. 2012. The hyporheic zone as an invertebrate refuge: a review of variability in space, time, taxa and behaviour. Marine and Freshwater Research 63:293-311.

Tachet, H., P. Richoux, M. Bournaud, and P. Usseglio-Polatera. 2002. Invertébrés d'eau douce ( $2^{\text {nd }}$ corrected impression). CNRS Éditions, Paris, France.

$\rightarrow$ Tockner, K., M. Pusch, D. Borchardt, and M. S. Lorang. 2010. Multiple stressors in coupled river-floodplain ecosystems. Freshwater Biology 55:135-151.

$\rightarrow$ Townsend, C. R., and A. G. Hildrew. 1994. Species traits in relation to a habitat templet for river systems. Freshwater Biology 31:265-275.

$\rightarrow$ van der Nat, D., K. Tockner, P. J. Edwards, J. V. Ward, and A. M. Gurnell. 2003. Habitat change in braided flood plains (Tagliamento, NE-Italy). Freshwater Biology 48:1799-1812.

$\rightarrow$ Vellend, M. 2010. Conceptual synthesis in community ecology. Quarterly Review of Biology 85:183-206. 
$\rightarrow$ Vinebrooke, R. D., K. L. Cottingham, M. S. J. Norberg, S. I. Dodson, S. C. Maberly, and U. Sommer. 2004. Impacts of multiple stressors on biodiversity and ecosystem functioning: the role of species co-tolerance. Oikos 104:451457.

$\rightarrow$ White, D. S. 1993. Perspectives on defining and delineating hyporheic zones. Journal of the North American Benthological Society 12:61-69. $\rightarrow$ Whittaker, R. H., S. A. Levin, and R. B. Root. 1973. Niche, habitat, and ecotope. American Naturalist 107:321-338.

Williams, D. D. 2006. The biology of temporary waters. Oxford University Press, New York.

$\rightarrow$ Wood, P. J., and P. D. Armitage. 2004. The response of the macroinvertebrate community to low-flow variability and supraseasonal drought within a groundwater dominated stream. Archiv für Hydrobiologie 161:1-20. 